\title{
房総半島南東岸の完新世前期の溺れ谷堆積物にみられる 地震隆起の痕跡と津波堆積物
}

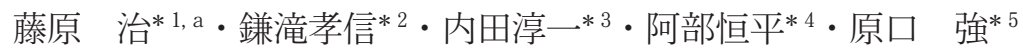

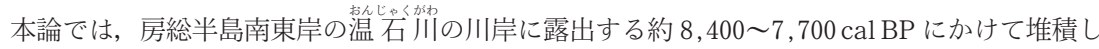
た溺れ谷堆積物の特徴と, そこに見られる地震隆起や津波の痕跡について報告する.

この露頭は最大高 $5 \mathrm{~m}$ 程度で, 泥層・砂層・砂啋層の互層加らなる. 堆積相解析, 貝化石之有 孔虫化石の分析, AMS による ${ }^{14} \mathrm{C}$ 年代測定値をもとに堆積環境の変遷を復元した結果, $8,200 \mathrm{cal}$ BP 頃に相対的海水準の一時的な低下か認められた。この現象は，地款变動の少ない東京湾沿岸 では, 後水期に 7,000 cal BP 頃のピークへ向けて相対的海水準が継続的に上昇したことと矛盾 し，調査地域での地震隆起を示していると考えられる。

泥層に挟まる砂層や砂磻層は, 溺机谷に流入した高潮や洪水, あるいは津波による堆積物と考 えられる. とくに $8,200 \mathrm{cal} \mathrm{BP}$ 頃の相対的海水準が低下寸る直前に堆積した砂砂層は, 海岸の隆 起を起こした地震に伴う津波堆積物である可能性が高い.

キーワード : 房総半島, 完新世, 溺れ谷堆積物, 地震隆起, 津波堆積物

\section{I. は じめに}

房総半島南東岸には完新世の海成段丘がよく発達し (横田, 1978 ; 中田ほか, 1980 ; 茅根・吉川, 1986), その 高度分布や離水時期に基づいて, 相対的海水準が最も高 かった約 7,300 cal BP 以降の海溝型地震の履歴が解明 されてきた (e.g., 宍倉, 2003 ; 川上・穴倉, 2006). 一方, 海成段丘の研究に比べると, この地域に分布する沖積層 に関する研究例は少ない. Sakai et al. (2004，2006) は荑 隅川低地 (図 1-A) を対象に, ボーリングデータや多数 の ${ }^{14} \mathrm{C}$ 年代測定値に基づいて約 $11,000 \mathrm{cal} \mathrm{BP}$ から 3,000 cal BP にわたる地層と地形の発達プロセスを復元した. そして, 後水期海進によって 7,000 cal BP 頃に, 最屯湾 が内陸まで広がり, その後に埋積されて海岸が前進した ことを明らかにした，彼らはまた，地形と地層の累重パ
ターンの変化から 9,000 cal BP 頃， 6,400 cal BP 頃およ び $3,500 \mathrm{cal} \mathrm{BP}$ 頃に地震隆起が起こったことを指摘し た. $9,000 \mathrm{cal} \mathrm{BP}$ 頃の地震隆起の認定には, 相対的海水 準の上昇期にもかかわらず, 堆積システムが一時的に海 側へ前進したことが根拠とされた。これは隆起した土地 で河川侵食や海蝕が強まり, 湾への堆積物の供給が増加 したためと考えられている (Sakai et al., 2004，2006). 房総半島南東部を流れる丸山川, 三原川, 沮若妿の下 流 (図 1-B) には, 河成段丘や隆起した完新統の露頭が 点在し, 横田 (1978) や鹿島 (1985) によって研究されて いる. その結果, この地層がおもに溺れ谷堆積物である こと, 完新世河成段丘群 (図 1-C) は完新世中期以降に 地震隆起によって, 間欠的に隆起・離水したことなどが 明らかにされた。

本研究では, 温石川の下流で新たに見出した露頭 (図

2008 年 4 月 5 日受付. 2008 年 9 月 27 日受理.

*1 産業技術総合研究所活断層研究センター $=$ \% 305-8567 つくば市東 1-1-1 中央第 7.

$* 2$ 応用地質株式会社 $\overline{\mathbf{T}} 336-0015$ さいたま市南区太田窪 2-2-19.

*3 熊本大学大学院自然科学研究科 $\overline{\mathbf{T}} 860-8555$ 熊本市黒髪 2 丁目 39-1 (現住所: 応用地質株式会社 $\overline{\mathbf{T}} 336-0015$ さいた ま市南区太田窪 2-2-19).

$* 4$ 筑波大学大学院生命環境科学研究科 $=305-8572$ つくば市天王台 1-1-1.

*5 大阪市立大学大学院理学研究科 $\overline{\mathbf{T}} 558-8585$ 大阪市住吉区杉本 3-3-138.

*a Corresponding author : o.fujiwara@aist.go.jp 


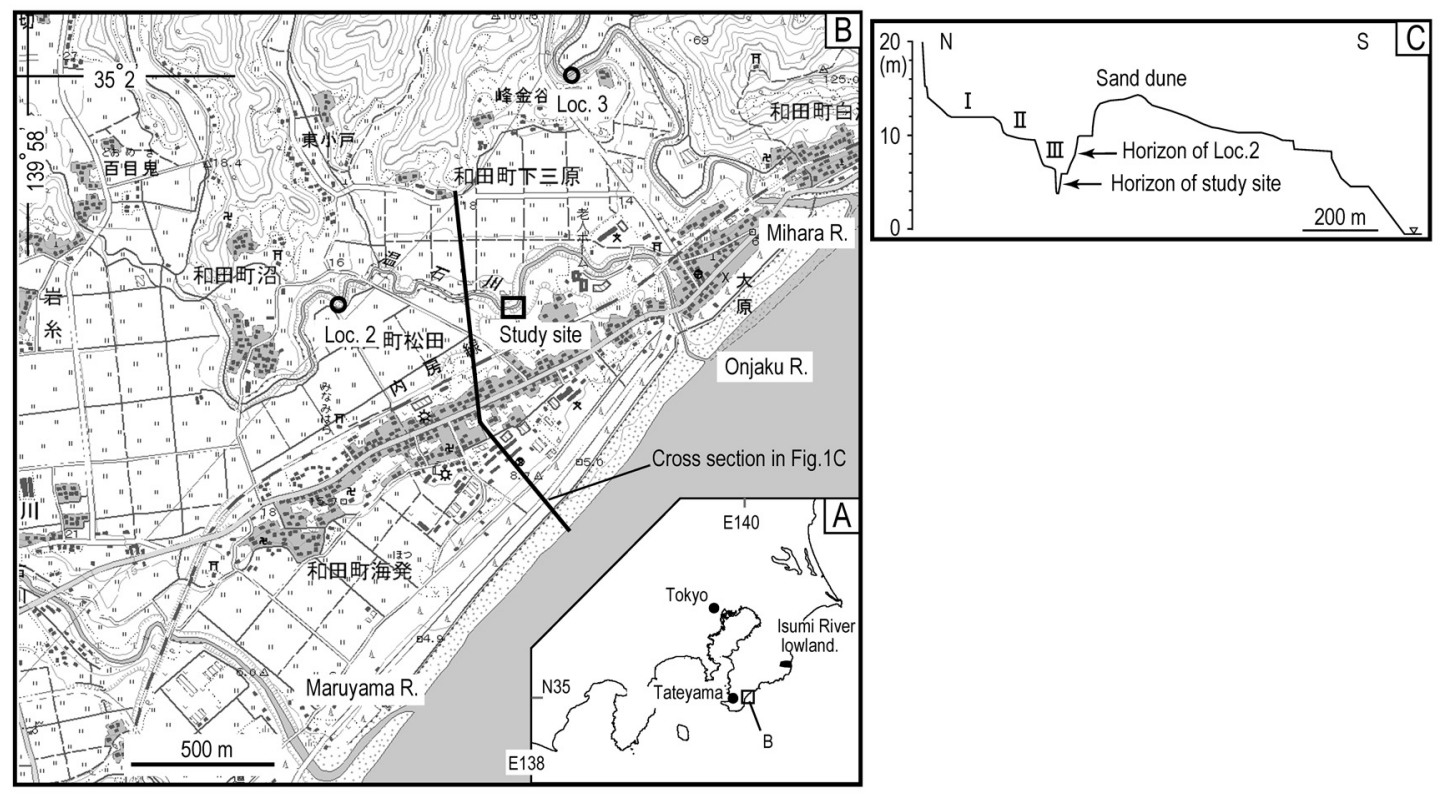

図 1 位, 置図

$\mathrm{A}$ : 研究対象地域. B : 調查地の地図. 1/25,000 地形図「安房古川」を使用. Locs. 2, 3 : 鹿島 (1985) が ${ }^{14} \mathrm{C}$ 年代測定を 行った露頭. C : 調査地の模式的な地形断面. 1/2,500 国土基本図から作成. I III : 丸山 I III 面(鹿島, 1985).

Fig. 1 Index map

A : Study area. B : Map showing the study site. Modified from 1/25,000-scale topographic map of Geogr. Surv. Inst., "Awafurukawa”. Locs. 2 and $3:{ }^{14} \mathrm{C}$ dating sites in Kashima (1985). C : Schematic cross section around the study site based on 1/2,500-scale topographic map of Wada Town. I-III : Maruyama Terraces I, II and III by Kashima (1985).

1-B) を研究対象とする. この露頭では, 堆積構造がよく 保存された溺れ谷堆積物の断面を幅 $80 \mathrm{~m}$ 以上にわたっ て連続して観察できる. この露頭の堆積相解析, 貝化石 と有孔虫化石の分析および $\mathrm{AMS}$ による ${ }^{14} \mathrm{C}$ 年代測定を 行った結果, $8,200 \mathrm{cal} \mathrm{BP}$ 頃に地震隆起が起こったこと や，その地震に伴う津波堆積物の可能性がある砂礫層を 見出したので報告する.

\section{II. 調 査 地 域}

房総半島南部の丘陵に源を発し太平洋へ注ぐ三原川, 丸山川, 温石川が集まる下流部には，小規模な沖積低地 が形成されている (図 1-B). この沖積低地は東西 $4.5 \mathrm{~km}$, 南北 $7.5 \mathrm{~km}$ 程度の広がりがあり, おもに新第三系三浦 層群や鮮新一更新統豊房層群（鈴木ほか，1990）がつく る丘陵を開析した谷に沿って複雑に入り込んだ形をして いる. 上記の河川に沿って 4 段の段丘が分布する(横田, 1978 ; 鹿島, 1985). 最高位の段丘はローム層に覆われる ことなどから更新世の段丘と考えられ, 他の 3 段の段丘
群は完新世の地震隆起によって形成されたと考えられて いる (鹿島, 1985). 図 1-C に, 調查地点周辺の模式的な 地形断面を示した. 完新世の段丘群は, その分布形態や 構成層の特徵から河成段丘と考えられ, 上位から順に丸 山 I 〜 III面と呼ばれている (鹿島, 1985). その離水時期 は特定されていないが, 鹿島 (1985) は丸山 I 〜 III 面の 海岸部での分布高度に基づいて, それぞれが房総半島南 東岸に分布する完新世海成段丘沼 $I ＼sim \mathrm{IV}$ 面 (中田ほか, 1980)に対比されることを示唆した.

この沖積低地の地層は, 横田 (1978), 鹿島 (1985), 千 葉県地質環境インフォメーションバンク (http: //wwwp. pref.chiba.lg.jp/pbgeogis/servlet/infobank.index)に よると, シルト層や粘土層を主とし, 砂層や礫層を時折 挟み, 層厚は最大で $30 \mathrm{~m}$ 以上に達する. 鹿島 (1985) は 層相, 珪藻化石亡貝化石の分析結果, ${ }^{14} \mathrm{C}$ 年代測定結果 (表 1 に，おもな結果を暦年較正して示す) から, 丸山 I 面を構成する堆積物を下部河成礫〜シルト層, 中部海成 泥層, 上部河成砂碟層に 3 区分した. そして, 下部河成 
表 $1{ }^{14} \mathrm{C}$ 年代測定に関するデー夕

Table $1{ }^{14} \mathrm{C}$ ages from study area

\begin{tabular}{|c|c|c|c|c|c|c|}
\hline 測定番号 & 試料 & $\begin{array}{l}\delta^{13} \mathrm{C} \\
(\%)\end{array}$ & $\begin{array}{c}{ }^{14} \mathrm{C} \text { 年代 } \\
(\text { yrs BP, } 10)\end{array}$ & $\begin{array}{l}\text { 暦年代 } \\
10 \\
\end{array}$ & $\begin{array}{c}\text { cal } \mathrm{BP}) \\
20 \\
\end{array}$ & 注記 \\
\hline JNC4484 & Ostrea denselamellosa & -1.23 & $7675 \pm 78$ & $8220-8020$ & $8320-7970$ & 離弁 \\
\hline JNC4485 & Cyclina sinensis & -0.57 & $7896 \pm 97$ & $8480-8260$ & $8570-8150$ & 離并 \\
\hline JNC4486 & Cyclina sinensis & -0.98 & $8005 \pm 83$ & $8550-8380$ & $8680-8300$ & 合弁 \\
\hline JNC4487 & 材化石 & -28.15 & $7413 \pm 53$ & $8320-8180$ & $8380-8150$ & \\
\hline JNC4488 & 材化石 & -12.49 & $7477 \pm 109$ & $8390-8180$ & $8460-8020$ & \\
\hline JNC4489 & 球果 & -24.80 & $7083 \pm 52$ & $7970-7850$ & $8010-7790$ & \\
\hline JNC4490 & 材化石 & -27.94 & $7144 \pm 51$ & $8020-7940$ & $8050-7840$ & \\
\hline JNC4491 & 材化石 & -30.59 & $7288 \pm 57$ & $8170-8040$ & $8200-7970$ & \\
\hline JNC4492 & 材化石 & -27.83 & $6938 \pm 89$ & $7850-7680$ & $7940-7610$ & \\
\hline JNC4493 & 材化石 & -26.54 & $7031 \pm 52$ & $7940-7820$ & $7970-7740$ & \\
\hline $\begin{array}{r}\mathrm{TK}-507 \\
\quad(\mathrm{Loc}\end{array}$ & $\begin{array}{l}\text { Cyclina sinensis } \\
2 \text { : 中部海成泥層) }\end{array}$ & $-0.4 \pm 1.6$ & $6546 \pm 61$ & $7150-6980$ & $7220-6900$ & $\begin{array}{l}\text { 元データは } \\
6880 \pm 60 \mathrm{BP}\end{array}$ \\
\hline $\begin{array}{l}\text { TK-443 } \\
\text { (Loc. } 3:\end{array}$ & $\begin{array}{c}\text { 材化石 } \\
\text { 下部河成礫〜シルト層) }\end{array}$ & $-27 \pm 3$ & $\begin{array}{r}10142 \\
\pm 118 \\
\end{array}$ & $\begin{array}{r}12050- \\
11600\end{array}$ & $\begin{array}{r}12250^{-} \\
11250\end{array}$ & $\begin{array}{c}\text { 元データは } \\
10100 \pm 100 \mathrm{BP}\end{array}$ \\
\hline
\end{tabular}

TK-443，TK-507 は鹿島 (1985) をもとに暦年較正した。

Samples TK-443 and TK-507 were calibrated from Kashima (1985) to calendric ages.

礫〜シルト層と中部海成泥層は $12,000 〜 11,000 \mathrm{cal} \mathrm{BP}$ 以降 (表 1) に後水期の海面上昇に伴って堆積したこと などを明らかにした.また鹿島 (1985) は, Loc. 2 (図1-B) に分布する中部海成泥層の標高 $8.0 \mathrm{~m}$ 付近から, オキシ ジミやイボウミニナなどの干潟に棲む貝化石群を見出

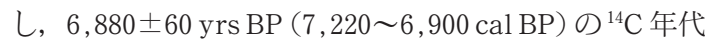
測定值を報告した（表 1)。この低地では，海成層の上限 高度が $18 \mathrm{~m}$ に達することから，7,220～6,900 cal BP よ りやや後に最高海面期を迎えたと推定される（鹿島, 1985).

本論文で記載する露頭は, 鹿島 (1985)の Loc. 2 より 約 $600 \mathrm{~m}$ 下流で, 標高が数 $\mathrm{m}$ 低い位置にあり, 現在の海 岸からは砂丘や浜堤を挟んで約 $700 \mathrm{~m}$ 離れている(図 1B). この露頭は高さが $2 \mathrm{~m}$ 前後で, ほぼ水平な地層が川 沿いに北東一南西方向に $80 \mathrm{~m}$ 以上連続して露出する. 露頭の南西端では, 幅数 $\mathrm{m}$ にわたり表土が崩れた部分 があり，そこではさらに上位の地層を観察できる. 露頭 で観察できる地層の層厚は約 $4.8 \mathrm{~m}$ である. 後述の砂礫 層 1 が標高 $3 \mathrm{~m}$ 付近に分布する $(1 / 2,500$ 国土基本図か らの読み取り値).

\section{III. 方 法}

層相の記載は, 露頭全体を概観するとともに, 堆積構 造の保存状態がよい露頭北東部に幅 $1 \mathrm{~m}$ 程度の「観察 空」を設定して行った (図 2-A)，「観察空」をねじり鎌で 整形して新鮮な地層面を露出させ, 遺跡調査や地層調査
などで用いられる親水性のグラウト剂を用いて，はぎ取 り試料を作成した (困 2-B). はぎ取り試料の作成方法は Takada and Atwater (2004) に詳しい.

「観察空」からは有孔虫化石の分析試料を阿部ほか (2004)の方法で採取した. すなわち, 整形した露頭面に L 字型のステンレス枠を左右から打ち込んで地層を柱状 に囲い，これを金属へラで露頭から切り出した. 切り出 した柱状試料（各長さ $500 \mathrm{~mm}$, 幅 $50 \mathrm{~mm}$, 奥行き 25 $\mathrm{mm})$ は計 4 本である. 実験室に持ち帰った柱状試料を 1 $\mathrm{cm}$ 間隔でスライスし, 凍結乾燥を施した. その後, 乾燥 試料の重量を測定し，250メッシュ（開口径 $63 \mu \mathrm{m}$ ) の篩 上で水洗した. 有孔虫化石の個体数が比較的少なかった ため, 残渣の分割は行わずに全個体を実体顕微鏡下で拾 い出した. 本研究では, 試料を約 $10 \mathrm{~cm}$ 間隔で検鏡した 結果を報告する.

露頭から採取した貝化石や球果など 10 試料について, 加速器質量分析計 (AMS) による ${ }^{14} \mathrm{C}$ 年代測定を核燃料サ イクル開発機構 (現日本原子力研究開発機構) で行った. また，鹿島 (1985) に示された ${ }^{14} \mathrm{C}$ 年代測定值について, $\delta^{13} \mathrm{C}$ を海生貝殼試料は $-0.4 \pm 1.6 \%$ （藤原ほか, 1999), 陸源試料は $-27 \pm 3 \%$ (Stuiver and Polach, 1977) とし て conventional age に補正し, その值をむとに暦年較正 した. 暦年較正プログラムは OxCal3.10 (Ramsey, 1995, 2001) を使用し, 較正デー夕はINTCAL04 (Reimer et al., 2004) と, Marine04 (Hughen et al., 2004) を使用した. この地域の海洋リザーバ効果は不明なので, 海洋の平均 

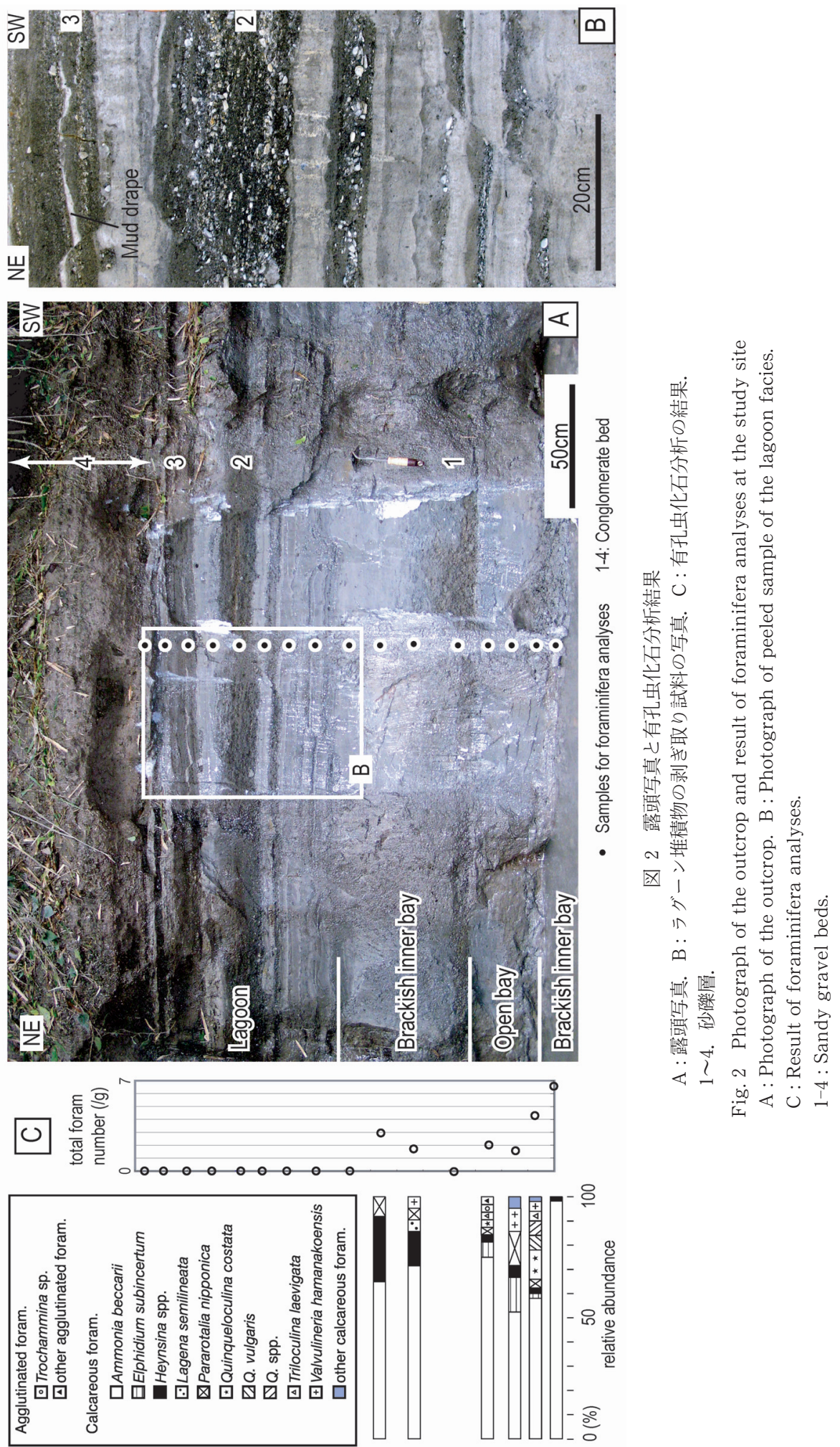
值（すなわち $\Delta \mathrm{R}=$ ゼロ）を用いた．測定に関する情報を 表 1 に示す.

\section{IV. 堆積相および化石の特徵}

露頭で観察される地層を, 層相, 貝化石および有孔虫 化石の特徵に基づて湾奥汽水域の堆積物, 内湾泥層, ラグーン堆積物に区分した（図 3). それぞれの堆積相 は，露頭全体を通じて側方へよく連続する，ただし，砂

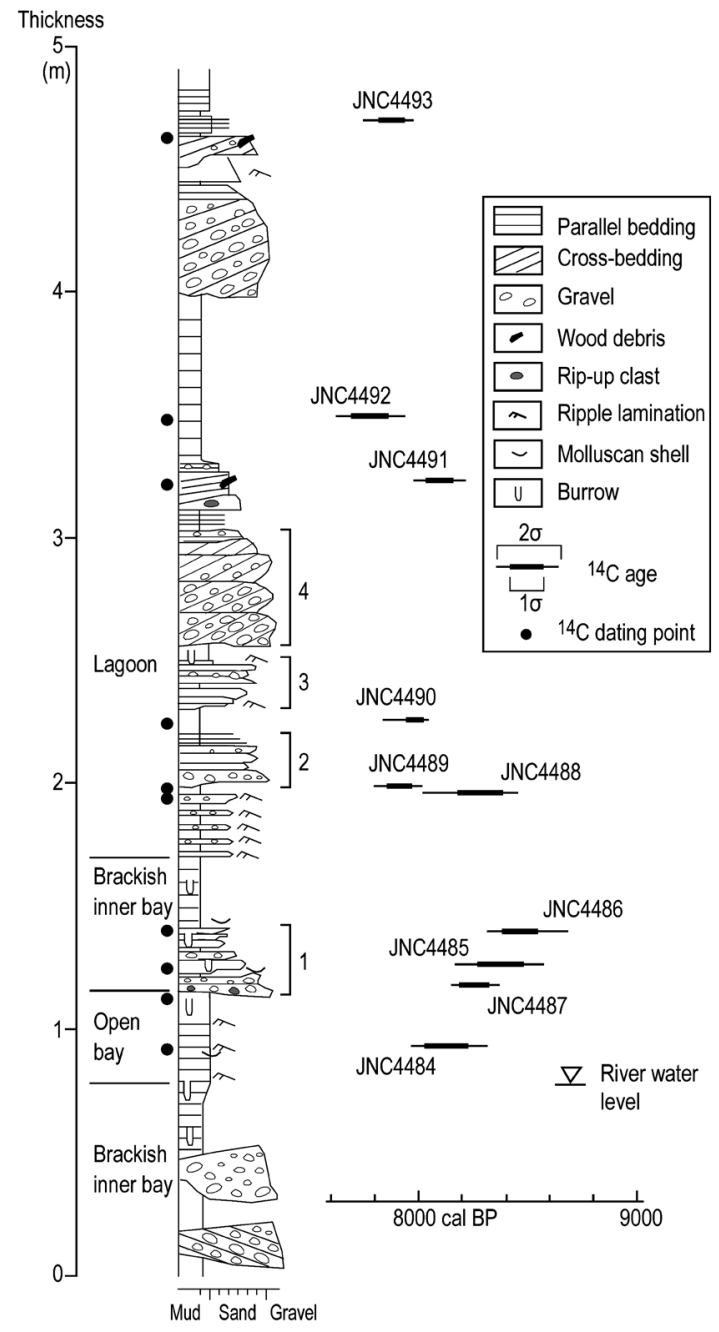

図 3 露頭の柱状図と ${ }^{14} \mathrm{C}$ 年代測定値 柱状図左のスケールは，露頭の観察できる下限を基底 とし，そこからの層厚で示す.

Fig. 3 Schematic columnar section and ${ }^{14} \mathrm{C}$ ages of the study site

Vertical scale shows the thickness of the sediment observed at the outcrop.
礫層による下位層の削り込みなどの影響で, 各堆積相の 層厚は側方へ多少変化する.

また，露頭では側方へよく連続する厚い砂碟層が 4 枚 見られる (図 2 および3の砂礫層 1４). 砂礫層 1～4 は露 出条件もよく, 内部構造を詳しく観察できた.これらは 津波堆積物の可能性があるので, 最後に一括して記載・ 解釈を行う。なお，図 3 では観察できた露頭の最下位の 層準を基準に，そこからの地層の層厚を示している.

\section{1. 湾奥汽水域の堆積物}

記載 : この堆積相は露頭の 2 つ層準で見られる. 1 つは図 3 の約 $80 \mathrm{~cm}$ よりも下位の層準である. この層準 は大部分が水没していて, 詳しい層相はわからないが, 巣穴状の生痕化石を含む死白色の粘土層で，中礫層を 2 層挟む．礫層は亜円礫からなり，層厚 $20 \mathrm{~cm}$ 前後で下位 層を削り込んでおり, 斜交層理が見られることがある. 粘土層からはAmmonia beccarii の卓越する多様性の低 い有孔虫化石群集が検出された (図 2-C).

もう 1 つは図 3 の 116 170 cm の層準で, 灰白色で塊 状の粘土層からなり, 巣穴状の生痕化石を含む. この粘 土層の基底に砂碟層 1 が見られる. この粘土層から検出 された有孔虫化石群集は, Ammonia beccarii がほとん どを占め, Heynsina spp.などを伴う (図 2-C).

解釈 : Ammonia beccarii は, 湾央から湾奥部に生息 し (Matoba, 1970), 低塩分環境に耐性がある種である. また, Heynesina spp. 屯湾奥部に生息する種である (小 杉ほか, 1991).

粘土層の層相と有孔虫化石の組成から，この堆積相は 閉鎖的な湾奥汽水域, すなわち淡水と海水が混じり合う 湾奥で堆積したと考えられる. 一方, 露頭最下部の礫層 は，基底の侵食面や斜交層理の発達する層相汃ら強い流 れで運ばれて堆積したと考えられるが, 水中に没してい るため, 詳細な堆積プロセスを議論する情報は得られて いない.

\section{2. 内湾泥層}

記載: この堆積相は, 図 3 の基底から $80 \sim 116 \mathrm{~cm}$ に かけての層準に見られ, 砂喕層 1 に覆われる.この層準 は生痕化石や植物片を含む死白色の砂質シルト層を主と し, 白色の粘土の薄層を頻繁に挟み, 砂質シルト層の一 部にはリップル葉理が見られる.この層準には離弁の Ostrea denselamellosa (イタボガキ)のほか, 貝化石の 破片が認められる. 下位層に比べて有孔虫化石の多様 性が高く, Ammonia beccarii に加えて Pararotalia nipponica, Quinqueloculina costata よ゙が随伴する (困 2C). また, 下部の 2 試料からは, わずかながら浮遊性有 
孔虫化石が確認された.

解釈 : リップル葉理を伴う砂質シルトと粘土層の細互 層は, 潮流の発生時に砂が移動し, 潮流の停滞時に浮遊 していた泥粒子などが沈降することで形成された潮汐堆 積物 (e.g., 増田ほか, 1988 ; Dalrymple et al., 1991 ; 坂 倉, 2004) と考えられる.

Pararotalia nipponica と Quinqueloculina costata は 岩礁地の海藻類に生息する葉上性種である(藤田ほか, 1999)。抒屯に外洋水に棲む浮遊性有孔虫の化石を含む ことも考慮すると, この堆積相は外洋水の影響を受ける 内湾で堆積したと考えられる.

\section{3. ラグーン堆積物}

記載: この堆積相は図 3 の基底から $170 \mathrm{~cm}$ より上位 の層準で, 粘土層・砂層・砂啋層の互層からなる. 粘土 層には砂質葉理が見られることがある.この堆積相は図 3 の基底から $256 \mathrm{~cm}$ 付近を境界に層相がやや異なるの で，上下に分けて記載する.

$256 \mathrm{~cm}$ 付近より下位 : この層準は下位層汃ら漸移し, 灰色の粘土層之砂層および砂磁層の細互層からなる. 砂 層は層厚 2 $5 \mathrm{~cm}$ のものが多い．この層準には砂砂層 2 と砂磁層 3 が見られる.これらの砂層や砂磁層は下位層 を削り込んで覆う。薄い砂層の多くは基底から逆級化し て, 中部が最む粗粒になり, 細一中碟を含む. 砂層の上 部は級化を示し, 波長数 $\mathrm{cm}$ のリップル葉理が発達し, その上を白色の粘土薄層が覆うことが多い (図 2-B). 碟 のインブリケーションからは， 1 枚の砂層の中で層準に よって北東と南西の両方向の古流向が読み取れることが ある. この層準からは有孔虫化石は産出しなかった。

$256 \mathrm{~cm}$ 付近より上位 : 炭質物に富む灰白色または白 色の粘土層を主とし, 最大層厚 $50 \mathrm{~cm}$ に達する䃇層や砂 層を 4 層挟む．このうち一番下位のむのが砂砂層 4 であ る. その他の砂層や砂層は露出範囲か狭く, 詳しい堆積 構造や側方変化は不明である. 砂礫層 4 の直上の砂層は, 斜交層理が見られ, リップアップクラストや植物片を含 み, 全体として上方細粒化する. 図 3 の基底加ら 400 $445 \mathrm{~cm}$ の層準を占める磻層は, 径 $5 \mathrm{~cm}$ 未満の亜円碟が 主で, 斜交層理が発達する.この砂層は全体として中部 が最む粗粒で，そこから上方へ細粒化し，上面を白色の 粘土薄層に覆われる. 図 3 の基底加ら 445〜 465 cm の層 準を占める砂層は, 上方細粒化する砂層が 2 枚重なった あので, 斜交層理やリップル葉理が発達し, 木片を含む.

解釈 : 河口域では海と陸から運び込まれる堆積物の量 比之, その運搬に関わる営力 (波浪・潮汐 ・河川) の相 対的な強度によって, 異なる堆積システムが形成される
(Dalrymple et al., 1992 ; 坂倉, 2004).この堆積相は有 孔虫化石屯生痕化石屯含まないので, 河川水の影響を強 く受けて堆積したと考えられる. 粘土層に潮汐の影響を 示す堆積構造が見られないことも，この解釈を支持す る. 植物根を含まないことは堆積時にある程度の水深が あったこと, 粘土層が卓越することは通常時には水の動 きが少なかったことを示している. Dalrymple et al. (1992) や坂倉 (2004) に示された河口域における堆積シ ステムとの比較からは, この堆積相の堆積場はラグーン が最も考えやすい.

粘土層之互層する砂層や礫層は, 砂や碩を多量に含む 流れから堆積した地層の特徵を持っている.これらは, ラグーンに強い流れが突入した痕跡と考えられ，その原 因としては高潮や洪水あるいは津波が考えられる.

\section{4. 津波堆積物の可能性がある砂碟層}

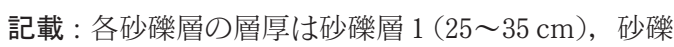
層 $2(8 \sim 22 \mathrm{~cm}$ ), 砂礫層 3 (最大 $20 \mathrm{~cm}$ ), 砂砂層 4 (約 50 $\mathrm{cm})$ である. これらの砂㗂層は下位の泥層を削り込んで 覆い, 次にあげる 3 つの特徴が共通して認められる.

（1）砂や砂啋の単層（層厚 1～数 $\mathrm{cm}$ ) とマッドドレイ プが繰り返し重なった構造を持つ.この構造は砂礫層の 上部で明瞭に見られるが，下部から中部にかけては単層 同士が癒着していることが多い. 上位の単層による侵食 を免れたマッドドレイプが砂磁層の中部でも見られるこ とがある(図 2-B)、マッドドレイプは植物片を多く含む こともある.（2）個々の単層は逆級化一級化構造を示す ことが多い, つまり, 基底から逆級化して中部で最す粗 粒になり, 中部から上部へは級化する. また, 個々の単 層には, しばしば斜交層理などが発達する.（3）上部ほど 細粒で薄い単層が重なり, 砂磁層全体としては上方細粒 化する.

また，個別の特徴として以下のことがあげられる，砂 啋層 1 は径 $2 \mathrm{~cm}$ 以下の碩が多く, Cyclina sinensis (才 キシジミ)や Batillaria zonalis (イボウミニナ)の化石 を含む. オキシジミの一部は合弁である. 砂碩層 2 と砂 礫層 3 は, 長径 1 2 cm 以下の扁平礫が多い. 砂砂層 2 では単層の内部にカレントリップルなどが見られ, 扁平 礫にはインブリケーションが見られるが, 正確な古流向 の復元はできていない. 砂磁層 4 は径 2 $3 \mathrm{~cm}$ の亜円磁 を主とするが，より大きな礫も含む．

解釈 : これらの砂砂層は, 露頭で数十 $\mathrm{m}$ もほぼ水平 に一定の層厚を保ちつつ連続して分布するので, 湾内の チャネルを充填したものではなく, シート状に広がって いると考えられる. (1) の特徵は, 砂磎層を形成する強い 
流れとマッドドレイプが堆積する流れの停滞期が繰り返 したことを示す.（2）の特徵は, 個々の単層が 1 回の流 れが弱まっていく過程で堆積したことを示す.（3）の特 徵は, 流れが何度も繰り返したこと, 後になるほど流入 する流れが弱まったことを示す.これらの特徵を併せ持 つことは, 長い周期で押し波と引き波が繰り返す津波で 堆積した地層の内部構造の特徵（藤原, 2007 ; Fujiwara and Kamataki, 2007) と調和的である.

しかし, 津波堆積物の重要な特徴である古流向が反転 を繰り返す構造は確認できてない，砂磁層 4 の一部で は, 礫のインブリケーションから上下の単層で逆向きの 古流向が推定されるが，礫の三次元配列を確認していな いので，厳密には流れの反転を確証できない.

\section{V. 堆積年代と相対的海水準変動}

ここでは, ${ }^{14} \mathrm{C}$ 年代測定值に基づいて各堆積相の堆積 年代を推定する. また, 堆積相の累重パターンから復元 される環境の変遷を相対的海水準変動と関連させて論じ る.

\section{1. 堆 積 年 代}

暦年較正した ${ }^{14} \mathrm{C}$ 年代測定值を図 3 に示した. 内湾泥層 の下部汃ら 8,320 7,970 cal BP (年代幅 $2 \sigma$, 以下同じ), 最上部から $8,380 \sim 8,150 \mathrm{cal} \mathrm{BP} の{ }^{14} \mathrm{C}$ 年代測定值が得 られた. 内湾泥層を覆う砂碟層 1 からは, 8,570〜8,250 cal BP と 8,680 8,300 cal BP の年代測定值が得られ た. この值は上・下位の試料に比べて, 年代がやや古い. その理由には, 海洋リザーバ効果が不確定であること や, 産状からは試料の貝殼が再堆積した可能性が考えら れる. 有意に古い年代值を除くと, ラグーン堆積物は 8,000〜 7,700 cal BP 頃に堆積したと考えられる.
ラグーン堆積物の層相（炭化物に富む粘土層・砂層・ 礫層の互層) は，鹿島 (1985) か報告した丸山 I 面堆積物 中の上部河成礫層や，より若い河成段丘を覆う河成層に 類似する. しかし, 堆積年代 $(8,000 \sim 7,700 \mathrm{cal} \mathrm{BP}$ 頃) と分布高度に基づくと, このラグーン堆積物はLoc. 2 (図 1-B) で見られる中部海成泥層の下位に位置する. し たがって，これは下部河成礫〜シルト層上部から中部海 成泥層の下部に相当する地層であり, 今回新たに識別さ れた堆積物である。

\section{2. 相対的海水準変動}

上記のデータとLoc. 2 (図 1-B) で推定された堆積環 境 (鹿島, 1985) を総合して, 堆積環境の変遷を図 4 に整 理した. この結果には, 水深の推定值, 潮差, 露頭の標 高值, 地層の圧密に起因する䛊差が含まれるが，相対的 海水準変動の傾向を議論することは可能である.

$8,400 \sim 8,300 \mathrm{cal} \mathrm{BP}$ 頃の汽水環境汃ら, 8,300〜8,200 cal BP 頃の内湾環境へと相対的海水準の上昇か認めら れる. 砂礫層 1 が堆積した直後 $(8,200 \mathrm{cal} \mathrm{BP}$ 頃) に再び 汽水環境となっており，相対的海水準が低下したことが 示唆される. 8,000〜 7,700 cal BP 頃までは, 海から隔離 されたラグーンの環境が続いており，この間については 海水準変動を復元するには情報不足である. しかし，こ の後海面が再び上昇したことは, Loc. 2 で標高 $8.0 \mathrm{~m}$ 付 近 $(7,220 \sim 6,900 \mathrm{cal} \mathrm{BP}$ 頃) に干潟の貝類群集が認めら れることと, 調査地域周辺では海成層上限高度が約 18 $\mathrm{m}$ とされること(鹿島, 1985) から明らかである.

\section{VI. 相対的海水準の低下が示す地震隆起}

相対的海水準の変動は, ユースタシー, 八イドロアイ ソスタシー, 地域的な地殼変動, 河口部での堆積作用な

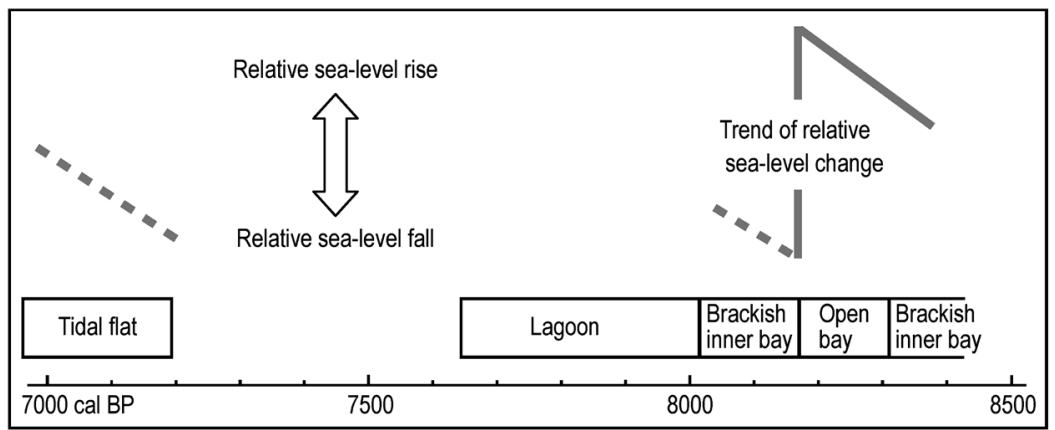

図 4 温石川流域の堆積相の重なりから復元された相対的海水準変動

Fig. 4 Relative sea-level change around the study area reconstructed from the stacking pattern of the depositional facies 
どが組み合って起こる. 個々の要因の区別は難しいが, 他地域の相対的海水準変動と比較することで, $8,200 \mathrm{cal}$ BP 頃に見られる相対的海水準の低下に, どの要因がよ り強く働いたかを推定した。

Sakai et al. (2004) は, 既存の研究を総合して東京湾 沿岸の $11,500 \mathrm{cal} \mathrm{BP}$ 頃から 6,000 cal BP 頃にかけての 相対的海水準変動曲線を描いた，それによれば，海面は 6,800 6, $600 \mathrm{cal} \mathrm{BP}$ 頃のピークに向かって上昇し, こ の間に海面上昇の停滞や低下は認められない. 東京湾沿 岸は海溝から離れており, 関東地震のような海溝型地震 による地殼変動が少ない地域であり, 温石川を含む房総 半島南東岸とはテクトニックセッティングが異なる.し たがって, 温石川で認められた $8,200 \mathrm{cal} \mathrm{BP}$ 頃の相対的 海水準の低下は, 地域的な隆起や河口部の堆積システム が海側へ前進したことが主因と考えられよう.この堆積 システムの前進は, Sakai et al. (2004, 2006) が夷隅川低 地で解釈したように, 隆起した地域で河川侵食が強ま り, そのために堆積物供給が増加したことも一因と考え られる. 調查地周辺には, 比較的時代が新しく固結の弱 い地層が分布しているので, それは十分起こり得ると考 えられる. また, 相対的海水準が低下する境界に挟まる 砂砂層 1 は, 地震隆起と関連した津波堆積物の可能性が 高い.

この相対的海水準の低下と直接対比できる海成段丘の 離水イベントは今のところ知られていない. 内房の館山 地域 (図 1-A) の内湾堆積物からは, 8,200 8,000 cal BP 前後に 2 枚の津波堆積物 (T2 および T2.1) が報告され ている(藤原ほか, 2003).これらの津波堆積物との対比 が確実になれば, 上記の相対的海水準の低下は地震隆起 に起因することがより明確になると考えられる.

\section{VII. ま と め}

房総半島南東岸に分布する完新世の溺机谷堆積物につ いて, 層相, 化石および ${ }^{14} \mathrm{C}$ 年代測定值から， 8,400 cal $\mathrm{BP}$ 頃から 7,700 cal BP 頃にかけての堆積環境を復元 し, 地震隆起と津波の痕跡を見出した.

1. 温石川で新たに見つかった露頭は, 泥層・砂層・ 砂砂層の互層からなり, この場所では時代とと屯に湾奥 汽水域, 外洋水の影響のある内湾, 湾奥汽水域, ラグー ンの順で環境が変化したことがわかった。

2. $8,200 \mathrm{cal} \mathrm{BP}$ 頃に相対的海水準の低下が推定さ れ, これは同時期に関東周辺などで相対的海水準が上昇 傾向にあったことと矛盾する. 相対的海水準低下の沶も な原因は, 地震隆起と河口周辺での堆積作用の相互作用
と考えられる.

3. 露頭では堆積構造の特徵から, 津波堆積物の可能 性がある砂碟層が少なくとあ4 層認められた. なかであ $8,200 \mathrm{cal} \mathrm{BP}$ 頃に堆積した砂砂層は, 上述した相対的海 水準の低下時期に対応しており, 海岸を隆起させた地震 に伴う津波堆積物の可能性が高い.

謝辞 北海道大学大学院地球環境科学研究院の平川一 臣教授, 熊本大学大学院自然科学研究科の長谷川四郎教 授, 島根大学総合理工学部の入月俊明准教授には露頭お よび研究室で議論していただき, 本研究を進める上で有 益であった. ${ }^{14} \mathrm{C}$ 年代測定值の暦年較正には, (株) パレ オ・ラボの伊藤 茂氏にご協力いただいた. 本稿は匿名 の查読者からのコメントによって改善された.

\section{引用文 献}

阿部恒平 - 内田淳一 - 長谷川四郎 - 藤原 治 - 鎌滰孝信 （2004）津波堆積物中の有孔虫組成の概要と殼サイズ 分布の特徴について一房総半島南部館山周辺に分布す る完新統津波堆積物を例にして一. 藤原 治・池原 研・七山 太編「地震イベント堆積物一深海汃ら陸上 までのコネクション」, 地質学論集, no. 58, 77-86.

Dalrymple, R.W., Makino, Y. and Zaitlin, B.A. (1991) Temporal and spatial patterns of rhythmite deposition on mud flats in the macrotidal Cobequid Bay - Salmon River Estuary, Bay of Fundy, Canada. Smith, D.G., Reinson, G.E., Zaitlin, B.A. and Rahamani, R.A. (eds.) Clastic tidal sedimentology : 137160, Canadian Society of Petroleum Geologists, Memoir, 16.

Dalrymple, R.W., Boyd, R. and Zaitlin, B.A. (1992) Estuarine facies models: conceptual basis and stratigraphic implications. Journal of Sedimentary Petrology, 62, 1130-1146.

藤田和彦 - 西 弘嗣 - 斉藤常正 (1999) 琉球列島沿岸海 草帯に生息する葉上性有孔虫類の季節変化. 化石, 66 , 16-33.

藤原 治 (2007) 地震津波堆積物 : 最近 20 年間のおむな 進展と残された課題. 第四紀研究，46，451-462.

Fujiwara, O. and Kamataki, T. (2007) Identification of tsunami deposits considering the tsunami waveform : an example of subaqueous tsunami deposits in Holocene shallow bay on southern Boso Peninsula, central Japan. Sedimentary Geology, 200, 295- 
313.

藤原 治 - 増田富士雄 - 酒井哲弥 - 入月俊明 - 布施圭介 （1999）房総半島と三浦半島の完新統コアに見られる 津波堆積物. 第四紀研究, 38, 41-58.

藤原 治・鎌滝孝信・田村 亨 (2003) 内湾における津 波堆積物の粒度分布と津波波形との関連一房総半島南 端の完新統の例一. 第四紀研究, 42, 67-81.

Hughen, K.A., Baillie, M.G.L., Bard, E., Beck, J.W., Bertrand, C.J.H., Blackwell, P.G., Buck, C.E., Burr, G.S., Cutler, K.B., Damon, P.E., Edwards, R.L., Fairbanks, R.G., Friedrich, M., Guilderson, T.P., Kromer, B., McCormac, G., Manning, S., Ramsey, C.B., Reimer, P. J., Reimer, R.W., Remmele, S., Southon, J.R., Stuiver, M., Talamo, S., Taylor, F.W. ; van der Plicht, J. and Weyhenmeyer, C.E. (2004) Marine04 marine radiocarbon age calibration, $0-26$ cal kyr BP. Radiocarbon, 46, 1059-1086.

鹿島 薫 (1985) 房総半島, 丸山川・和田川流域の完新 世の地形発達. 地理学評論, 58, 734-743.

茅根 創・吉川虎雄（1986）房総半島南東岸における現 成・離水浸食海岸地形の比較研究. 地理学評論, 59, $18-36$

川上俊介・宍倉正展（2006）館山地域の地質. 地域地質 研究報告 (5 万分の 1 地質図幅), $82 \mathrm{p}$, 産業技術総合 研究所地質調査総合センター.

小杉正人・片岡久子・長谷川四郎 (1991) 内湾域におけ る有孔虫の環境指標種群の設定とその古環境復元への 適応. 化石, 50, 37-55.

増田富士雄・ 中山尚美 - 池原 研 (1988) 茨城県行方郡 北浦内宿の更新統にみられる 9 日間の潮流によって形 成された斜交層理．筑波の環境研究，11，91-105.

Matoba, Y. (1970) Distribution of recent shallow water foraminifera of Matsushima Bay, Miyagi Prefecture, northeast Japan. Science Report of Tohoku University, 2nd ser. (Geology), 42, 1-85.

中田 高 - 木庭元晴 - 今泉俊文 · 曹 華龍 - 松本秀明 · 菅沼 健（1980）房総半島南部の完新世海成段丘と地 殻变動. 地理学評論, 53, 29-44.

Ramsey, C.B. (1995) Radiocarbon calibration and analysis of stratigraphy : The OxCal program. Radiocarbon, 37, 425-430.

Ramsey, C.B. (2001) Development of the radiocarbon program. Radiocarbon, 43, 355-363.

Reimer, P.J., Baillie, M.G.L., Bard, E., Bayliss, A., Beck, J.W., Bertrand, C.J.H., Blackwell, P.G., Buck, C.E., Burr, G.S., Cutler, K.B., Damon, P.E., Edwards, R.L., Fairbanks, R.G., Friedrich, M., Guilderson, T.P., Hogg, A.G., Hughen, K.A., Kromer, B., McCormac, G., Manning, S., Ramsey, C.B., Reimer, R.W., Remmele, S., Southon, J.R., Stuiver, M., Talamo, S., Taylor, F.W., van der Plicht, J. and Weyhenmeyer, C.E. (2004) IntCal04 terrestrial radiocarbon age calibration, 026 cal kyr BP. Radiocarbon, 46, 1029-1058.

Sakai, T., Fujiwara, O. and Kamataki, T. (2004) Tectonic uplifts recorded in topography and borehole successions in the Isumi River lowland, mid Boso Peninsula, central Japan. Fujiwara, O., Ikehara, K. and Nanayama, F. (eds.) Earthquake-induced event deposits - From deep-sea to on land. The Memoirs of the Geological Society of Japan, no. 58, 51-62.

Sakai, T., Fujiwara, O. and Kamataki, T. (2006) Incisedvalley-fill succession affected by rapid tectonic uplifts : An example from the uppermost Pleistocene to Holocene of the Isumi River lowland, central Boso Peninsula, Japan. Sedimentary Geology, 185, 21-39.

坂倉範彦（2004）潮汐環境の堆積物：日本の干潟の理解 に向けて. 化石, 76, 48-62.

宍倉正展（2003）変動地形から見た相模トラフにおける プレート間地震サイクル. 地震研究所彙報, 78，245254

Stuiver, M. and Polach, H.A (1977) Discussion : Reporting of ${ }^{14} \mathrm{C}$ data. Radiocarbon, 19, 355-363.

鈴木尉元・览玉喜三郎・三梨 昂 (1990) 那古地域の地 質. 地域地質研究報告 (5 万分の 1 地質図幅), 48 p, 地質調查所

Takada, K. and Atwater, B.F. (2004) Evidence for liquefaction identified in peeled slices of Holocene deposits along the lower Columbia River, Washington. Bulletin of the Seismological Society of America, 94, 550-575.

横田佳代子（1978）房総半島南東岸の完新世海成段丘に ついて. 地理学評論, 51, 345-364. 


\title{
Early Holocene coseismic uplift and tsunami deposits recorded in a drowned valley deposit on the SE coast of the Boso Peninsula, central Japan
}

\author{
Osamu Fujiwara*1, a , Takanobu Kamataki*2, Jun-ichi Uchida*3 \\ Kohei Abe*4 and Tsuyoshi Haraguchi*5
}

This paper discusses a coseismic uplift which occurred around 8,200 cal BP along the southeast Boso Peninsula on the Pacific coast of central Japan facing the Japan Trench and Sagami Trough. Estimated uplift is based on eleven ${ }^{14} \mathrm{C}$ ages and analyses of sedimentary facies, fossil assemblages of foraminifera and mollusks from the outcrops along the Onjaku River. The deposit is represented by alternation of mud, sand, and gravel beds deposited in a drowned valley system.

The results suggest that the relative sealevel rapidly fell around $8,200 \mathrm{cal} \mathrm{BP}$. This phenomenon is discordant with the relative sea- level curve obtained from the Tokyo Bay area of small tectonic movements, which indicates a continuous relative sea-level rise toward a peak around 7,000 cal BP. Relative sea-level fall estimated from the study area probably reflected a local tectonic uplift.

Sand and gravel beds alternating with mud beds might be deposited by storm surges, river floods, and/or tsunamis that intruded into the muddy drowned valley. The conglomerate bed deposited just before the relative sea-level fall around 8,200 cal BP is interpreted as a tsunami deposit caused by the same earthquake that uplifted the study area.

Keywords : Boso Peninsula, Holocene, drowned valley deposit, coseismic uplift, tsunami deposit

*1 Active Fault Research Center, National Institute of Advanced Industrial Science and Technology. Tsukuba Central 7, 1-1-1 Higashi, Tsukuba, 305-8567, Japan.

*2 OYO Corporation. 2-2-19 Daitakubo, Minami-ku, Saitama, 336-0015, Japan.

*3 Graduate School of Science and Technology, Kumamoto University. 2-39-1 Kurokami, Kumamoto, 8608555, Japan (Present address : OYO Corporation. 2-2-19 Daitakubo, Minami-ku, Saitama, 336-0015, Japan).

*4 Graduate School of Life and Environmental Sciences, the University of Tsukuba. 1-1-1 Tennodai, Tsukuba, 305-8572, Japan.

*5 Graduate School of Science, Osaka City University. 3-3-138 Sugimoto, Sumiyoshi-ku, Osaka, 558-8585, Japan.

*a Corresponding author : o.fujiwara@aist.go.jp 